\title{
Pedagogia czterech progów wiary w biblijnej katechezie dorosłych Mess'AJE
}

\section{THE PEDAGOGY OF THE FOUR THRESHOLDS OF FAITH IN THE BIBLICAL CATECHESIS OF ADULTS MESS'AJE}

The catechesis of adults is considered as the principal form of catechesis. The Church is constantly looking for methods and forms of catechesis appropriate for an adult recipient. The biblical catechesis of adults Mess'AJE is one of the interesting catechetical proposals, which has enjoyed success in France and in many other countries around the world.

The foundation of the pedagogy of faith is the Bible, and its source is divine pedagogy. What constitutes the originality of the pedagogy of adult catechesis Mess'AJE, is the proposal of travelling through the history of the faith of God's people in the Bible. It is the history of salvation containing milestones - the so-called "thresholds of faith", which becomes the history of acts of faith to remain faithful to God. The catechized know the history of the faith of God's people and they discover in it their own history. Professor Jacques Bernard, the founder of this catechesis, shows in the Bible four thresholds of faith: Exodus, Exile, Jesus, The Church. Each catechetical meeting, according to the Mess'AJE approach, includes five elements: presentation and discussion of audiovisual material inspired by the Bible, biblical and historical approach, theological approach, sharing in groups, prayer.

Key words: catechesis, Mess'AJE catechesis, catechesis of adults, biblical catechesis, pedagogy of faith. 
Teologia pastoralna

\section{Wprowadzenie}

W Dyrektorium katechetycznym Kościoła katolickiego w Polsce czytamy, że „katecheza dorosłych uznawana jest w dokumentach katechetycznych Kościoła za problem wielkiej wagi i najznakomitszą formę katechezy"1. Istotnie, od Soboru Watykańskiego II - kiedy to postulowano m.in. przywrócenie katechumenatu dorosłych ${ }^{2}-\mathrm{w}$ refleksji katechetyczno-pastoralnej dostrzega się pilną potrzebę katechezy dorosłych, motywując ową troskę powszechnym doświadczeniem³ ${ }^{3}$. W kwestii zainteresowania katechezą dorosłych praktyka zdaje się jednak nie nadążać za teorią. $\mathrm{Z}$ jednej strony bowiem, katecheza nadal kojarzona jest często z lekcją religii w szkole, a jej odbiorcami w powszechnym przekonaniu są dzieci i młodzież. Z drugiej zaś strony, dorośli uświadamiają sobie braki w formacji religijnej, stając w obliczu pytań, na które nie są w stanie udzielić odpowiedzi. Próba szukania pomocy w Biblii kończy się niejednokrotnie zniechęceniem i frustracją powodowaną natłokiem trudnych imion, nazw miejscowości lub wydarzeń, które czasem mogą zaskakiwać, czy wręcz szokować.

Biblijna katecheza dorosłych Mess'AJE, która zrodziła się we Francji w roku 1970 dzięki francuskiemu egzegecie ks. Jacquesowi Bernardowi, stanowi oryginalną odpowiedź na potrzebę formacji dorosłych - odpowiedź, która znalazła już wielu odbiorców w Europie i w świecie. Co sprawia, że w wielu krajach, w tym w Polsce w Archidiecezji Białostockiej, podejmuje się trud tłumaczenia materiałów na języki narodowe, szukania animatorów, formowania grup katechetycznych i prowadzenia regularnych spotkań katechetycznych dla dorosłych metodą Mess'AJE? Co stanowi o oryginalności i uniwersalności katechezy? Odpowiedź na te pytania zawarta jest w tytule: Pedagogia czterech progów wiary.

$1 \quad$ Konferencja Episkopatu Polski,Dyrektorium katechetyczne Kościoła katolickiego $w$ Polsce, 98.

2 Zob. Sobór Watykański II, Dekret o pasterskich zadaniach biskupów Christus Dominus, 14.

3 Zob. Kongregacja ds. Duchowieństwa, Ogólna instrukcja katechetyczna (Directorium Catechetisticum Generale), 92; Jan Paweł II, Adhortacja apostolska o katechizacji w naszych czasach Catechesi tradendae (dalej: CT), 43; Kongregacja ds. Duchowieństwa, Dyrektorium ogólne o katechizacji (dalej: DOK), 171-176. Katecheza dorosłych stała się przedmiotem zainteresowań m.in. ks. D. Kurzydło, Koncepcja katechezy dorostych we wspótczesnych dokumentach Kościoła, Kraków 2003. Warto również sięgnąć do pracy zbiorowej pod redakcja ks. K. Misiaszka, Katecheza dorostych we wspólnocie Kościoła, Warszawa 2002, w której to publikacji znajdziemy m.in. artykułE. Młyńskiej, Katecheza dorostych we Francji, s. 277-304. Autorka pisze w nim również o katechezie Mess'AJE. 


\section{Pedagogia wiary}

Na jakiej podstawie można mówić o pedagogii wiary? Czy rzeczywistość wiary pozwala się ująć w kategoriach ludzkich, pedagogicznych, odwołujących się do wychowania? Jeśli - według Katechizmu Kościoła Katolickiego - ,wiara jest najpierw osobowym przylgnięciem człowieka do Boga; równocześnie i w sposób nierozdzielny jest ona dobrowolnym uznaniem całej prawdy, którą Bóg objawił"4, to w jaki sposób wpłynąć na tajemnicę spotkania łaski Bożej z wolnością osoby ludzkiej? W Adhortacji apostolskiej Catechesi tradendae Jan Paweł II określił jednak katechezę mianem „wychowania w wierze”, wskazując przy tym na dwie inne funkcje katechezy: na nauczanie i wtajemniczenie $^{5}$. Te trzy funkcje katechezy uwypuklają jej trzy różne wymiary. Mówienie o katechezie jako wychowaniu w wierze zakłada pragnienie, by katecheza kształtowała postawy, ożywiając i wspomagając wiarę, nawet jeśli to oddziaływanie nie ma charakteru bezpośredniego, lecz tylko pośredni. Chodzi o integralną formację osoby ludzkiej, tj. sfery cielesnej, intelektualnej i duchowej, o kształtowanie żywej relacji z Bogiem i wychowanie do dialogu z Nim, o otwarcie na wspólnotę Kościoła i inkulturację wiary ${ }^{6}$.

Fundamentem pedagogii wiary jest Biblia, a źródłem tejże pedagogii jest Boża pedagogia. W Dyrektorium ogólnym o katechizacji czytamy, że „zbawienie człowieka [...] ukazuje się także jako owoc właściwej i skutecznej «pedagogii Bożej» w ciągu historii"7. Istotnie, Bóg jest „genialnym i przenikliwym wychowawcą”, który poucza, formuje i prowadzi swój lud ${ }^{8}$. Pedagogię Boga Ojca i Syna kontynuującego „pedagogię Bożą," kontynuuje z kolei Kościół - „nauczyciel naszej wiary" ${ }^{10}$. Według Dyrektorium, katecheza „inspiruje się pedagogią Bożą, jaka rozbrzmiewa w Chrystusie i w Kościele"11. Z jednej strony nie miesza działań pedagogicznych człowieka z działaniem łaski Bożej, z drugiej zaś strony nie przeciwstawia ich ani nie rozdziela. Zasada wierności Bogu i człowiekowi staje się prawem obowiązującym

$4 \quad$ Katechizm Kościoła Katolickiego (dalej: KKK), 150.

5 Zob. CT, 18.

$6 \quad$ Zob. W. Cichosz, Pedagogia wiary we wspótczesnej szkole katolickiej, Warszawa 2010; A. Orczyk, Pedagogia wiary, „Katecheta” 42 (1998) 6-7, s. 24-31.

7 DOK, 139.

8 Por. ibidem.

9 Por. ibidem, 140.

$10 \quad$ Zob. KKK, 169; DOK, 141.

11 DOK, 143. 
Teologia pastoralna

w pedagogii wiary - prawem, według którego katecheza podejmuje wysiłek pomocy w rozpoznawaniu działania Boga poprzez postawę „słuchania, dziękczynienia i modlitwy” oraz prowadzenia katechizowanego do wolnej odpowiedzi i uczestnictwa ${ }^{12}$. Przed katechezą stoi zatem „nigdy niekończące się zadanie znalezienia języka zdolnego do komunikowania słowa Bożego i Credo Kościoła, które jest jego rozwinięciem, w różnych warunkach słuchaczy”, skoro Bóg zwraca się do ludzi jak do przyjaciół i przystosowuje „swoje mówienie do kondycji ziemskiej"13.

Biblijna katecheza dorosłych Mess'AJE, będąca przedmiotem naszej refleksji, chce być wierna Bogu i człowiekowi, szanując działanie łaski Boga i wysiłek człowieka, oraz pragnie inspirować się Bożą pedagogią. Proponuje jednak coś, co stanowi o jej oryginalności, a mianowicie katechetyczną wędrówkę przez historię wiary ludu Bożego zawartą w Biblii. Pismo Święte opowiada o stopniowym odkrywaniu Boga przez naród, któremu Bóg towarzyszy w jego wędrówce. Droga, jaką należy pokonać, nie jest z góry wyznaczona ani nie jest prosta. Zawiera bowiem momenty przełomowe, wymaga podejmowania ważnych decyzji, przeżywania zmiennych okresów oraz przekraczania progów - progów wiary. Jest to historia wiary ${ }^{14}$.

\section{Biblia jako historia wiary}

Rzeczownik „historia” należy do wyrazów powszechnie używanych. Jednak jest on różnie rozumiany, a jego zakres semantyczny jest dość szeroki. W związku z tym katecheza Mess'AJE rozróżnia potrójne jego znaczenie: „historia” jako dyscyplina naukowa, „historia święta” i „historia Zbawienia" 15 .

Po pierwsze historia jest nauką humanistyczną i społeczną. Historycy badają archiwa, źródła archeologiczne i wszelkie świadectwa. Starają się zrekonstruować fakty, ukazując związek przyczynowo-skutkowy badanych zdarzeń. Pomagają zrozumieć przeszłość, stawić czoła teraźniejszości i przygotować się na przyszłość. Praca historyczna

$12 \quad$ Zob. ibidem, 144-145.

13 Ibidem, 146; por. Sobór Watykański II, Konstytucja dogmatyczna o Objawieniu Bożym Dei Verbum, 13.

14 C. Le Peltier (red.), Les Seuils de la Foi. Entrer dans la foi avec la Bible. Jalons pour une catéchèse d'adultes, Paris 2009, s. 9.

15 Zob. ibidem, s. 21; E. Młyńska, Biblia w katechezie dorostych w ujęciu Jacquesa Bernarda, „Studia Katechetyczne”, t. 8; Kerygma, Biblia, katecheza, R. Czekalski (red.), Warszawa 2012, s. 325-326. 
w odniesieniu do Biblii pozwala odkryć w niej naród o określonej tożsamości, lud, który odwołuje się do swojej pamięci, ma swoje wierzenia i podkreśla swoją tożsamość, czego świadectwem są teksty biblijne ${ }^{16}$.

Drugie rozumienie historii $\mathrm{w}$ pedagogii czterech progów wiary to „historia święta”. Chodzi tu o chronologię wydarzeń znaną z układu ksiąg biblijnych: stworzenie, Adam, potop, Abraham, Mojżesz, wyjście z Egiptu, król Dawid, wygnanie, prorocy itd. Jest to „scenariusz” własnych dziejów ułożony przez naród po powrocie z wygnania - scenariusz, który powstał w określonej epoce, w perspektywie teologicznej. Jako chrześcijanie, odczytując tę historię świętą w świetle wydarzenia Jezusa Chrystusa, dostrzegamy niekiedy pewne niezgodności między nią a historią powszechną. Historia święta jest bowiem wynikiem kompozycji teologicznej, co nie zmienia faktu, że zasługuje na miano historiii ${ }^{17}$.

Wreszcie trzecie ujęcie historii sytuuje się gdzieś pomiędzy historią świętą a archeologią. Jest to „historia Zbawienia”. Celem nie jest tu zrekonstruowanie wydarzeń historycznych, przez które Bóg przyniósł Zbawienie. Chodzi raczej o nakreślenie historii wiary, tj. historii aktów wiary ludu biblijnego podejmowanych, by trwać w wierności Bogu. Te akty wiary są głęboko zakorzenione w wydarzeniach historycznych, które niekiedy wprost są możliwe do wskazania. Katecheza Mess'AJE i jej pedagogia czterech progów wiary wpisują się właśnie w tę perspektywę historii Zbawienia, czyli „historii wiary”. Katechizowany jest zaproszony do tego, by odkrywać drogę wiary ludu biblijnego, przeżywać z nim istotne momenty, pokonywać kolejne etapy-progi ${ }^{18}$.

\section{Historia ludu biblijnego a nasza historia}

Biblia w katechezie Mess'AJE jawi się jako świadectwo dialogu między Bogiem a Jego ludem w historii. Każdy z progów wiary stanowi wezwanie i łaskę, jaką pragnie On ofiarować człowiekowi. Boża pedagogia polega na tym, że Stwórca stopniowo objawia siebie w dziejach ludu, który zachowuje w pamięci wydarzenia zbawcze. Kolejne progi wiary prowadzą do coraz głębszej relacji z Bogiem, lecz człowiek pozostaje wolny w swej odpowiedzi. Na przykład, w czasach Jezusa niektórzy spośród Żydów w sposób radykalny poszli za Nim; inni natomiast skazali Go na śmierć ${ }^{19}$.

$16 \quad$ Les Seuils de la Foi. Entrer dans la foi avec la Bible..., op. cit., s. 21.

17 Ibidem, s. 22.

18 Ibidem, s. 23.

19 Zob. ibidem, s. 23-24. 
Zaproponowana w pedagogii czterech progów wiary katechezy Mess'AJE droga indukcji, tj. poznawania Objawienia przez stopniowe odkrywanie ewolucji w wierze ludu biblijnego, różni się więc od ujęcia dedukcyjnego, w którym zgłębia się usłyszane uprzednio Słowo Boże. Zdaniem Jacquesa Bernarda, należy najpierw umożliwić dorosłemu poznanie etapów rozwoju wiary człowieka biblijnego i jego dochodzenia do uznania Jedynego Boga. Do czytania Biblii potrzebne jest poznanie historii, która nadała kształt wierze ludu Bożego i wierze Kościoła $^{20}$.

Teologia pastoralna

Lud Boży, czytając Biblię, odkrywał w niej swoją własną historię. Niejako przedłużał historię biblijną i aktualizował ją. Podobnie jest z historią życia każdego człowieka. Człowiek, analizując bieg swojego życia, dostrzega różne etapy i momenty, z których niektóre posiadają szczególne znaczenie. Dostrzega interwencje Boga, nawet jeśli nie do końca wie, kim ten Bóg jest. Tak oto biblijna katecheza dorosłych Mess'AJE jest nie tylko opowiadaniem o historii wiary ludu Bożego od początku aż po Credo Kościoła, nie tylko opowiadaniem o wydarzeniach towarzyszących narodzinom wiary, jej pogłębianiu i o stopniowym objawianiu się Boga, lecz jest nieustannym odwoływaniem się do naszej historii życia i historii naszej wiary. Dzięki temu jest to katecheza żywa i dynamiczna. Jacques Bernard osadził na realiach historycznych proces dojrzewania wiary - nie tylko wiary ludu Biblii, ale wiary każdego z nas ${ }^{21}$.

\section{Cztery progi wiary w Biblii}

Według francuskiego egzegety, twórcy katechezy Mess’AJE, można wskazać cztery istotne etapy w dziejach ludu biblijnego, cztery momenty przełomowe w historii Zbawienia, czyli cztery progi wiary. $\mathrm{Z}$ pewnością nietrudno jest domyślić się istotnego momentu - progu, jakim było przejście ze Starego do Nowego Testamentu i Nowego Przymierza w Chrystusie. Jednak nie był to jedyny przełom w historii wiary w Biblii. A zatem, jakie są pozostałe progi wiary, czyli te momenty, w których konieczne było podejmowanie nowych aktów wiary?

20 Zob. E. Młyńska, Biblia w katechezie dorostych w ujęciu Jacquesa Bernarda, op. cit., s. 323-324.

21 Zob. B. Skłodowski, Biblia, sztuka, katecheza. Rozmowa z ks. prof. Jacquesem Bernardem, Catherine Le Peltier i Bertille Vernier $z$ Uniwersytetu Katolickiego $w$ Lille we Francji, twórcami biblijnej katechezy dorostych Mess'AJE, którzy gościli w Białymstoku $w$ dniach 3-7 marca 2014 r., „Drogi Miłosierdzia”, kwiecień 2014, nr 4 (44), r. 5, s. 32. 
Pierwszy próg nosi nazwę „Wyjście” i opowiada dzieje narodzin wiary biblijnej. Naród odkrywa obecność i działanie Boga, od którego wszystko otrzymuje i dzięki któremu zwycięża, bo sam jest małym narodem i dysponuje skromnym orężem. Zwycięstwo Izraelitów pod wodzą Debory i Baraka nad wojskami kananejskimi (Sdz 4-5), wyzwolenie z niewoli egipskiej (Wj 14-15), przejście przez Jordan (Joz 3-4) to trzy charakterystyczne doświadczenia „wyjścia” - wyzwolenia dzięki interwencji Boga. Na pierwszy próg wiary składa się stopniowe wychodzenie z systemu religii naturalnych, odejście od pogańskich praktyk religijnych na rzecz relacji Przymierza z Bogiem Wybawicielem.

Drugi próg to „Wygnanie”. Obejmuje on doświadczenie próby, jakiej zostało poddane Przymierze z Bogiem w związku z wygnaniem (tzw. niewolą babilońską czy przesiedleniem babilońskim). Czy Bóg Wyzwoliciel pamięta o swoim ludzie? - pytano. Zawirowania wygnania babilońskiego pogłębiły jednak relację Przymierza. Był to czas proroków i czas odkrywania Boga, który objawiał się w ciszy jako Bóg miłujący, Bóg Jedyny, Stworzyciel wszechświata. Pozorna nieobecność Boga pośród nieszczęść przyczyniła się do pogłębienia wiary jako relacji z Bogiem Przymierza, zdolnym przemieniać serca. Tożsamość narodu wybranego budowana była wokół kapłanów, świątyni i Tory.

Trzeci próg nosi tytuł „Jezus”. Chodzi o moment spotkania dwóch nurtów wiary żydowskiej tamtego czasu - judaistycznego i apokaliptycznego - z Jezusem z Nazaretu, głoszącym Królestwo Boże, miłosierdzie i przebaczenie. Jezus wypełnił Prawo i głęboko je odnowił. Dla Żydów był to kolejny etap do pokonania - kolejny próg: odtąd to sam Jezus jest nową Torą i nową Świątynią. Trzeci próg jest zatem historią przyjęcia albo odrzucenia Jezusa Chrystusa i zainaugurowanego przez Niego Królestwa Bożego.

Czwarty próg nosi nazwę „Kościól”. To historia rodzącej się wspólnoty Kościoła po pozornej porażce i zgorszeniu krzyża. Jezus Chrystus zmartwychwstał i to Zmartwychwstanie zmieniło rzeczywistość w sposób radykalny. Uczniowie doświadczyli obecności Zmartwychwstałego i tego, jak po Wniebowstąpieniu pozostał w swoim Kościele, w sakramentach świętych. Dzięki Duchowi Świętemu Ewangelia może być głoszona wszystkim narodom - Żydom i poganom. A Kościół - wspólnota dynamiczna i żywa, w której trwa historia Zbawienia jest wezwany, by żyć nowością przyniesioną przez Jezusa Chrystusa. Tak oto katechetyczna wędrówka przez cztery progi wiary prowadzi 
do odkrycia Boga, który wkroczył w historię, stopniowo objawiał się człowiekowi i pozwalał mu poznać swój zbawczy plan ${ }^{22}$.

Katecheza czterech progów wiary rozłożona jest zazwyczaj na cztery lata, choć nie jest to obligatoryjne. Jednemu rokowi odpowiada wówczas jeden próg wiary. Na każdy z progów przypada około 12-15 spotkań katechetycznych, trwających od półtorej do dwóch godzin. Każde spotkanie zawiera pięć istotnych elementów. Rozpoczyna się od prezentacji materiału audiowizualnego inspirowanego Biblia, który staje się punktem wyjścia do dzielenia się na temat tego, co zostało

Teologia pastoralna przedstawione (1). Następnie animatorzy katechezy sięgają do tekstów biblijnych i do ich historii (2). Kolejnym elementem jest odniesienie się do teologii i próba zrozumienia, w jaki sposób Bóg objawia się na danym etapie historii (3), po czym następuje czas dzielenia się w małych grupach. To moment aktualizacji usłyszanych i przeżytych treści poprzez odniesienie do własnego życia (4). Spotkanie kończy modlitwa wynikająca $\mathrm{z}$ tematu spotkania $(5)^{23}$.

\section{Zakończenie}

W świetle przeprowadzonej refleksji katecheza Mess'AJE oparta na pedagogii czterech progów wiary jawi się jako interesująca propozycja dla wszystkich dorosłych. Nie zakłada ona bowiem konieczności posiadania podstaw w postaci określonego zasobu wiadomości, poziomu intelektualnego, czy poziomu rozwoju wiary. Nie polega też na usystematyzowanym przekazie prawd teologicznych, co dla niektórych odbiorców stanowiłoby poważną barierę. W katechezie Mess'AJE nie chodzi o przekaz teorii, lecz o pedagogię wiary. Teologia została bowiem wpisana w całość pasjonującej wędrówki rozumianej jako odkrywanie historii wiary ${ }^{24}$.

Biblijna katecheza dorosłych Mess'AJE z powodzeniem prowadzona jest dziś nie tylko we Francji i nie tylko w Europie, lecz również w Afryce, Ameryce Północnej i w Azji. Wiele dobrego może się stać za jej przyczyną również w Polsce. Wczytujmy się zatem w historię wiary ludu biblijnego, by odkrywać w niej naszą historię i wzrastać w poznawaniu i umiłowaniu Pisma Świętego.

$22 \quad$ Zob.Les Seuils de la Foi. Entrer dans la foi avec la Bible..., op. cit., s. 12-13, 20-23; E. Młyńska, Biblia w katechezie dorostych..., op. cit., s. 330-340. s. 3. 
Słowa kluczowe: katecheza, katecheza Mess'AJE, katecheza dorosłych, katecheza biblijna, pedagogia wiary.

\section{Bibliografia:}

1. Cichosz W., Pedagogia wiary we wspótczesnej szkole katolickiej, Warszawa 2010.

2. Czekalski R. (red.), Kerygma, Biblia, katecheza, Warszawa 2012.

3. De Visscher M., Une catéchèse audiovisuelle pour adultes, [w:] L'Exode. Dieu fait Alliance avec son peuple. Guide d'animation (2 ${ }^{\mathrm{ème}}$ édition), Lille 2005.

4. Jan Paweł II, Adhortacja apostolska o katechizacji w naszych czasach Catechesi tradendae.

5. Kongregacja ds. Duchowieństwa, Dyrektorium ogólne o katechizacji.

6. Kongregacja ds. Duchowieństwa, Ogólna instrukcja katechetyczna (Directorium Catechetisticum Generale).

7. Konferencja Episkopatu Polski, Dyrektorium katechetyczne Kościoła katolickiego $w$ Polsce.

8. Kurzydło D., Koncepcja katechezy dorostych we wspótczesnych dokumentach Kościoła, Kraków 2003.

9. Le Peltier C. (red.), Les Seuils de la Foi. Entrer dans la foi avec la Bible. Jalons pour une catéchèse d'adultes, Paris 2009.

10. Misiaszek K. (red.), Katecheza dorostych we wspólnocie Kościoła, Warszawa 2002.

11. Młyńska E., Biblia $w$ katechezie dorostych $w$ ujęciu Jacquesa Bernarda, „Studia Katechetyczne”, t. 8.

12. Młyńska E., Katecheza dorostych we Francji, [w:] K. Misiaszek (red.), Katecheza dorostych we wspólnocie Kościoła, Warszawa 2002.

13. Orczyk A., Pedagogia wiary, „Katecheta” 42 (1998) 6-7.

14. Skłodowski B., Biblia, sztuka, katecheza. Rozmowa z ks. prof. Jacquesem Bernardem, Catherine Le Peltier i Bertille Vernier $z$ Uniwersytetu Katolickiego w Lille we Francji, twórcami biblijnej katechezy dorostych Mess'AJE, którzy gościli w Białymstoku w dniach 3-7 marca 2014 r., ,Drogi Miłosierdzia", kwiecień 2014, nr 4 (44), r. 5.

15. Sobór Watykański II, Dekret o pasterskich zadaniach biskupów Christus Dominus.

16. Sobór Watykański II, Konstytucja dogmatyczna o Objawieniu Bożym Dei Verbum. 